\title{
Podcast: 10 questions with Canada's prison watchdog
}

$\mathrm{C}$ anada's new Liberal government must soon decide whether to follow through on plans to replace Correctional Investigator Howard Sapers.

Earlier this year, the former Conservative government gave Sapers a temporary contract pending his replacement.

Since 2004, Sapers has challenged the government's treatment of Aboriginal offenders and inmates with mental illness.

Although the criminal justice system is doing a better job of identifying the special needs of these populations, outcomes aren't improving, he says.

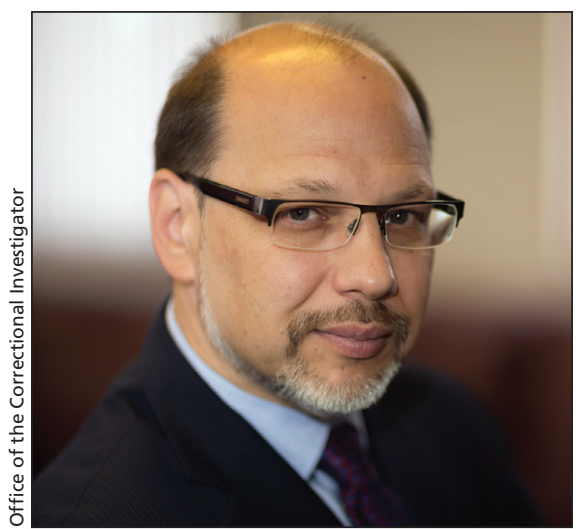

More offenders with mental illness should be diverted to health care, not prison, says Howard Sapers.
"We're seeing just as much or more self-injury, just as much or more suicide and suicide attempts, just as much or more institutional violence," Sapers explains. "All of these are indicators of an unhealthy prison environment."

In this CMAJ podcast interview, Sapers reflects on his term as prison watchdog, solutions to the justice system's health worker shortage, and next steps for better inmate health. - Lauren Vogel, CMAJ

Tune in at SoundCloud.com

CMAJ 2015. DOI:10.1503/cmaj.109-5190 